\title{
Another report smiles on human genome sequencing project
}

\section{Washington}

CONGRESS's own research agent, the Office of Technology Assessment (OTA), last week produced at a congressional hearing a reflective report* on the project to map the human genome. While applauding the project, the report differs from many other on the topic in exploring hitherto neglected ramifications of the project.

Although the OTA effort began life as the 'human genome project', the report makes it quite clear that other than human species will ultimately play a role in understanding the genetic information gleaned from mapping projects.

OTA also seeks to defuse the contentious notion that a genome project would be solely concerned with constructing a complete sequence of the 3,000 million nucleotide base pairs that make up the human genome. Although this may be an ultimate goal, the OTA report points out that physical maps, genetic linkage maps, clone repositories and genetic databases will all become available as a result of the project, and will have immediate utility for the biological sciences.

The report also says that genome projects are not in the same category as "big science' projects such as the Manhattan Project or the Apollo programme to land a man on the Moon. The component parts of genome projects do not require the same scale of spending, and the technical goals are not nearly so sharply focused.

Congress will probably find the section in the report on organization the most useful. In unusually forthright terms, the report says that the appointment of a single lead agency to run the project would be fraught with problems. OTA warns that the process of selecting a lead agency "would delay progress and diminish overall funding".

Instead, OTA seems to lean towards an interagency task force to coordinate the various efforts of the National Institutes of Health, the Department of Energy and the National Science Foundation, each of which would support some component of the project. In this respect, OTA differs from the National Research Council's report on the human genome project, which advocated a single lead agency (see Nature 331,467;1988).

The report also raises some difficult issues relating to patents, copyrights and technology transfer that will arise as private companies and foreign governments join federally supported research laboratories in working on the project.

The report also says that there will be

Mapping our Genes: The Genome Projects: How Big, How Fast? Office of Technology Assessment, Washington DC, 1988. difficult ethical and social problems. For example, genetic mapping will undoubtedly provide more effective diagnostic tools for the detection of disease, but diagnostics seems inevitably to precede the development of effective therapies. Eugenic issues will also need attention as a better picture of genomic organization emerges.

The lack of progress in resolving these issues has prompted biotechnology critic Jeremy Rifkin to form a coalition pushing for more congressional attention to the social ramifications of genome projects. Rifkin's coalition, drawn from a wide spectrum including ethics specialists, labour leaders, members of women's health organizations, insurance watchdog groups and disabled rights groups, intends to work for a human genome policy board to advise Congress on the implications of genome research.

Congress has already taken up this issue (see below), but so far not especially effectively. Rifkin says he has no objection to spending money on mapping and sequencing efforts, so long as public concerns about the project are heard.

LeRoy Walters, director of the centre for bioethics at the Kennedy Institute of Ethics and chairman of the OTA advisory panel on mapping the human genome, agrees that scholarly ethical research must proceed in tandem with biological work. Otherwise, Walters says, ethical problems will be upon us before we have decided how we want to cope with them.

Joseph Palca

In typical bureaucratic style, Congressional interest in the mapping and sequencing of the human genome has spawned proposals to create panels and review boards to evaluate and manage the project. Legislation to focus the organization of the project and direct its role in enhancing national "competitiveness" has been entered in both houses of Congress. But what of ethical issues?

To fill the gap, plans have been laid in Congress to resuscitate a Biomedical Ethics Board originally set up in 1985 to wrangle with issues such as fetal research and genetic screening. The board of six Senators and six Congressmen has been languishing for the past two and a half years, divided over the composition of its advisory committee and its stance on the issue of abortion. The selection of committee members was completed three weeks ago.

Whether the board finally will get off to a start by grappling with the ethical questions posed by the human genome project remains to be seen.

Carol Ezzell

\section{SE Asia drug centre}

THE World Health Organization (WHO) has established a centre on drug information at the Central Drug Research Institute at Lucknow in India. The centre, the first of its kind established by WHO, will in the first instance run for four years. It will act as a focal point for information on drugs for the 11 states that comprise the South East Asia region. The centre will develop and maintain an information base on sources of drug manufacture, prevailing prices and registration, and patent status. In addition, it will train WHO fellows in aspects of drug information services.

Of particular importance will be the centre's role in helping member states to decide whether to register drugs - several developing countries have not yet established effective mechanisms for drug registration, which has led to allegations of unscrupulous marketing by pharmaceutical manufacturers.

S.H.

\section{Universities win battle}

THE Cape Supreme Court has dismissed with costs an application for leave to appeal against the setting aside of subsidy conditions imposed on the University of Cape Town (UCT) by the South African government last year. On the same day, the state withdrew an application for leave to appeal against the setting aside of identical conditions imposed on the University of the Western Cape (UWC).

Delivering judgement on 31 March, $\mathrm{Mr}$ Justice Howie said that there was no reasonable chance that such an appeal would succeed. In February, the court ruled that the conditions imposed on both UCT and UWC were invalid, and last month the Natal Supreme Court made a similar ruling for the University of Natal.

This means that the universities have won the legal battle to have the regulations declared invalid, as the case cannot be referred to the Appeal Court in Bloemfontein. The prospect remains that Minister of National Education F.W. de Klerk may decide to put legislation before parliament to effect the conditions he wants. M.C.

\section{ACOST speaks out}

ACOST, the British government's Advisory Council on Science and Technology, has made a rare public announcement. Following a meeting earlier this month chaired by the Prime Minister, Mrs Margaret Thatcher, the council last week issued a statement that it has commissioned the Natural Environment Research Council (NERC) to prepare a report on the "extent and effectiveness of involvement by the UK in research on the global environment" and "the importance of global environmental research to the UK for government, economy and society". The council also wants to examine the potential for industry to exploit environmental research. S.H. 